\title{
Reference method for the erythrocyte sedimentation rate (ESR) test on human blood
}

The following document is based on the report of the expert panel on the erythrocyte sedimentation rate test ${ }^{1}$. It has been reviewed and endorsed by appropriate national and international organizations and its publication has been approved by the ICSH Board.

\section{Aim}

The purpose has been to recommend an international reference method for the ESR test on human blood in order to provide a guide for the setting out of national standards and to specify the constructional dimensions of the equipment required to ensure a meaningful comparison of data obtained in different laboratories throughout the world.

\section{Principle}

The ESR test measures the sedimentation rate of aggregated red cells in plasma.

The numerical value in $\mathrm{mm}$ is obtained by measuring the distance between the lowest point of the surface meniscus to the upper limit of the red cell sediment in a column of anticoagulated and diluted blood that has stood in a selected tube for a period of 60 minutes.

This empirical phenomenon depends upon an interrelationship of a number of inherent variables. In addition there are certain environmental and technical factors which may influence the test in misleading ways. The reference method is intended to control and eliminate the latter as far as possible.

\section{Method}

The Westergren method is recommended as the basis for an acceptable standard. Blood is obtained

\footnotetext{
${ }^{1}$ The expert panel on the erythrocyte sedimentation rate test established by the Third General Assembly of the International Committee for Standardization in Hematology (Strasbourg, 1965) comprised K-G.v. Boroviczeny (Berlin), L. E. Böttiger (Stockholm), A. Chattás (Buenos Aires), J. B. Dawson (Rochester), K. Fukutake (Tokyo), F. W. Gunz (Christchurch), S. M. Lewis (London), E. Rewald (Mar del Plata; Chairman), M. Roubicek (Mar del Plata; Secretary), G. Ruhenstroth-Bauer (München), and A. Westergren (Stockholm; died 15 Dec. 1968).
}

Correspondence to Dr. S. M. Lewis, Royal Postgraduate Medical School, London W12. by clean venepuncture over a maximum period of 30 seconds, and thoroughly mixed in a proportion of 4 volumes of blood to 1 volume of filtered solution of sodium citrate. At room temperature, the test must be set up within two hours, or at $4^{\circ} \mathrm{C}$ within six hours. For the test, any sample showing evidence of agglutination when checked with a magnifying glass should be discarded. The blood-citrate is thoroughly mixed by gentle repeated inversion and a clean dry standard Westergren-Katz tube is filled and adjusted to the 0 mark. The tube is then placed in a strictly vertical position under room temperature conditions $\left(18-25^{\circ} \mathrm{C}\right)$, not exposed to direct sunlight and free from vibrations and draughts.

After this time period the distance from the bottom of the surface meniscus to the top of the column of sedimenting red cells (where the full density is apparent) is read in $\mathrm{mm}$ and recorded as the ESR value. The result is expressed as follows: ESR (Westergren $1 \mathrm{~h})=\mathrm{mm}$.

\section{Materials}

1 ANTICOAgUlant-Diluent SOlution Trisodium citrate dihydrate $\left(\mathrm{Na}_{3} \mathrm{C}_{6} \mathrm{H}_{5} \mathrm{O}_{7} .2 \mathrm{H}_{2} \mathrm{O}\right)$

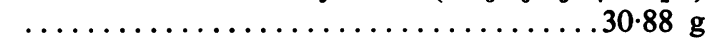
Distilled water $\ldots \ldots \ldots \ldots \ldots \ldots$ to 11

The solution is filtered through a sterile membrane, maximum pore diameter $0.22 \mathrm{~mm}$, into a sterile container and kept without preservatives. It must be discarded if turbid.

\section{WESTERGREN-KATZ TUBE}

A The tube must be made of thick-walled glass tubing, which is straight, colourless, free from visible defects and internal strain. The upper end must be ground smooth, square with the longitudinal axis, and have a suitable bevelled edge: the lower end must be tapered, finely ground and similarly square with the axis.

B The tube must conform to the following dimensions: (a) overall length $300 \pm 1.5 \mathrm{~mm}$ : (b) tube bore $2.55 \pm 0.15 \mathrm{~mm}$ : (c) uniformity of tube bore $\pm 0.05 \mathrm{~mm}$

C The tube must possess the following markings: (a) the inscription 'Westergren': (b) the scale, graduated in $\mathrm{mm}$, extending over the lower $200 \pm$ 
0.35 mm. Maximal tolerated error between two subsequent $\mathrm{mm}$ markings is $\mathbf{0 . 2} \mathrm{mm}$. Graduations should be fine, clearly marked lines of uniform thickness $(0.2 \mathrm{~mm})$ and numbered from 200 at the bottom up to 0 in steps of 10 or less.

\section{Appendix}

1 Contamination with skin cleaning materials during the venepuncture should be avoided.

2 If the laboratory ambient temperature is other than $18-25^{\circ} \mathrm{C}$, it should be noted with the ESR value.

3 Blood samples for ESR test can be obtained without regard to the patient's circadian rhythm and meals.

4 For re-utilization, the glass tubes must be cleaned in an acetone-water system. Use of dichromate and detergent mixtures is not recommended.

5 When evaluating an ESR test, additional factors should be considered such as haemoglobin level, $\overrightarrow{\vec{F}}$ age, sex, menstrual cycle, pregnancy, drugs taken (corticoids, contraceptive pills, etc).

6 Values for 'normal' ESR are not given in this international recommendation. Each National Committee should offer a range which includes 90 or $95 \%$ of the local healthy population.

7 There is not yet sufficient evidence as to the $\vec{\circ}$ extent to which the ESR may be affected by $(a)$ blood collection into a container with a solid anti- $\vec{\omega}$ coagulant: (b) tubes made by a material other than glass: (c) micromethods.

The Panel wishes to encourage further investi- N gation into these three important areas so that for routine use alternatives to the reference method may be available. 